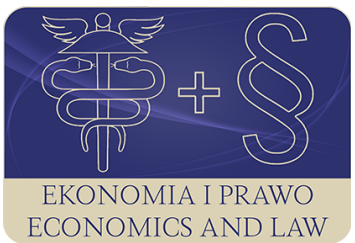

EKONOMIA I PRAWO. ECONOMICS AND LAW

Volume 20, Issue 2, June 2021

p-ISSN 1898-2255, e-ISSN 2392-1625

www.economicsandlaw.pl

ORIGINAL ARTICLE

received 28.04.2021; revised 20.06.2021; accepted 30.06.2021

Citation: Ostoj, I. (2021). The structure of gig workers in the global online gig economy by country of origin and its institutional foundations. Ekonomia i Prawo. Economics and Law, 20(2), 337-351. https://doi.org/10.12775/EiP.2021.020.

\title{
The structure of gig workers in the global online gig economy by country of origin and its institutional foundations
}

\author{
IZABELA OSTOJ \\ University of Economics in Katowice, Faculty of Economics, Department of Economics, \\ ul. 1 Maja 50, 40-287 Katowice, Poland \\ ๑izabela.ostoj@ue.katowice.pl \\ orcid.org/0000-0003-2997-280X
}

\begin{abstract}
Motivation: The online gig economy, where labour is provided via specialized digital platforms, is an important element of the platform economy. This market is developing on a global scale. The structure of supply in the online gig economy and the reasons for the domination of gig workers from specific countries are still the areas remaining rela-

tively under-researched.

Aim: The article aims to examine the supply side of the online gig economy based on the country of origin of gig workers, as well as to explain the reasons why gig workers from specific countries have dominated the sector.

Results: The analysis of the data from the Oxford Internet Institute proved that the supply of online labour services in the global market is dominated by three Asian countries India, Pakistan, Bangladesh — as well as the USA and the United Kingdom. The preliminary investigation into the determinants of the supply of labour services indicates that the countries under research have developed favorable institutional conditions, such as the universal knowledge of the English language, the right proportion of Internet users

to the population size, the large informal sector, and considerable labour freedom.
\end{abstract}

Keywords: gig workers; platform mediated work; Online Labour Index; institutions JEL: J21; J46; O33 


\section{Introduction}

Nowadays, digitalization contributes to the growth in platform mediated work. The gig economy as a relatively new economic category is related to the digital economy and forms a segment of the economy where services provided by many independently operating contractors (gig workers or platform workers), microtasks or projects, are coordinated with demand from buyers (businesses or consumers) through specialized digital platforms, also referred to as digital labour platforms (Hunt \& Samman, 2019, pp. 6-7; ILO, 202la, pp. 46-51; Minter, 2017, pp. 438-454; Stewart \& Stanford, 2017, pp. 420-437). These platforms enable tasks to be performed online or offline (Bogenhold et al., 2017, pp. 2332; Howcroft \& Bergvall-Kåreborn, 2019, pp. 21-38). The growth of the online gig economy attracts particular interest as it allows orders and services to cross national borders through internet access and knowledge of how relevant platforms work, without the necessity to travel or commute. This creates the global market of the online gig economy in which both clients/employers and gig workers from different countries can potentially participate (Graham \& Anwar, 2019). It becomes a substitute for migration processes. Its analysis is difficult because gig workers usually do not register their activity officially and regulation that accounts for the transnational nature of such activities and protects the interests of all parties involved is absent. Research shows that especially gig workers, the supply side of the global online services market, suffer from exposure to the negative consequences of the lack of adequate regulation (Kessler, 2018, pp. 93-138; Prassl, 2018, pp. 71-90). Accordingly, it is of importance to investigate what countries gig workers come from and what underlies the formation of a particular supply structure in the global market of the online gig economy in terms of gig workers' home country. It is worthwhile to examine which determinants of the supply of labour services play a role and how they can be researched.

The article aims to examine the supply side of the global online gig economy by country of origin of gig workers and to explain the underlying reasons for its structure. It presents the arguments supporting the thesis of the institutional nature of the factors determining the origin of online gig workers. Work provided through digital platforms is usually performed in the informal sector, so it is not measured in the countries of origin or it is estimated together with other economic activities in this sector. The measurement of the online gig economy, however, can be conducted with a tool developed by the Oxford Internet Institute (OII), which can also be used to examine the supply structure of the global online gig economy (Kässi \& Lehdonvirta, 2018, pp. 241-248). The article presents the position of the online gig economy in the platform economy and the general characteristics of the measurement of the online gig economy using the Online Labour Index (OLI). In the methods section it discusses the use of the OLI tool to analyse the supply side of the online gig economy. Further, it presents the selection of factors explaining the supply structure of gig 
workers by country of origin and the results of the analysis. The interpretation of the findings is given in the discussion section and summarised in the conclusion section. The article is based on the data from the OII and international organizations, as well as topical reference literature.

\section{Literature review}

\subsection{The online gig economy as part of the platform economy}

One of the consequences of the digitalization of modern economies is the development of the platform economy and digital platforms, which are its fundamental component (Farrell \& Greig, 2016, pp. 19-21; Radonjic-Simic \& Pfisterer, 2019 , pp. 1-44). By nature, they serve the direct or indirect communication of the parties who want to conclude a transaction. Parker et al. (2016, pp. 11-15) argue that the digital platform is a business that enables value creation through interactions between external producers (suppliers) and buyers, as it provides and manages open participatory infrastructure for these interactions. Thus, the prime goal of the platform is to build the conditions for the exchange of goods or services and, as a result, to create value for all its participants. Platforms that mediate labour services are developing intensively. Stewart \& Stanford (2017, pp. 420-437) classified platforms according to the subject of exchange and they distinguished capital platforms, i.e., platforms that mediate the rental or sale of assets, and labour platforms, i.e., platforms that mediate the provision of labour services (which are the foundation of the gig economy).

Based on the findings of Florisson \& Mandl (2018, p. 2) and Stanford (2017, pp. 382-401), several typical characteristics can be attributed to platform mediated work: (1) activity is primarily motivated by end users - consumers or businesses, although it can also be initiated by contractors and platforms; accordingly, a triangle of relationships emerges: gig worker — client - mediating platform; (2) a task is usually commissioned by the buyer (a business or a consumer), while the gig worker waits in expectation; (3) gig workers provide work when their service is purchased, in response to the demand, with no guarantee of continued activity; (4) the paid performance of a task is coordinated through a platform and often takes the form of separate activities larger projects are broken down into; (5) work is remunerated only based on individual tasks performed and upon approval by the client; payment corresponds to a single effect such as an activity, a task or a product and is usually unrelated to the time involved; (6) gig workers are required to provide a place where a service is delivered and other equipment, such as a smartphone or a computer, which implies costs that are difficult to estimate; (7) the platform acts as an intermediary in the commissioning of the task, the assessment of its performance and the transfer of the outcome to the client, as well as in the payment of the remuneration, thus creating the rules for the use of the platform by the parties concerned. These condi- 
tions make gig workers vulnerable to the instability and irregularity of work and income, the low level of payment in relation to the time spent on waiting for and performing the task, the lack of regulations ensuring the remuneration and costs that are difficult to estimate, which causes that this type of work is precarious (Prassl, 2018, pp. 106-107).

Howcroft \& Bergvall-Kåreborn (2019, pp. 21-38) proposed a model typology of crowdwork platforms according to the initiating actor and the stability of payment. They distinguished four types of platforms, of which the first three relate to work performed online: (l) so-called micro-tasks (e.g., MTurk or Upwork), (2) projects performed by freelancers (e.g., apps for Apple), (3) collaborative projects and complex problems solved by a network community, (e.g., InnoCentive.com), (4) platforms mediating work carried out offline, for payment and within limited territorial reach (e.g., TaskRabbit or Uber).

This typology corresponds with the classification introduced by Bogenhold et al. (2017, p. 23-32) and further developed in the ILO (2021a) report, which distinguishes: (1) platforms for online work - online web-based platforms; (2) platforms mediating offline work - work on demand via apps, (De Stefano, 2016, p. 5), performed in a traditional way, offline - location-based platforms.

Accordingly, the majority of platforms mediating the provision of labour services involve online activities. The major characteristic of the online gig economy is that it crosses national borders and creates a global market for labour services, which is difficult to measure because workers in the online gig economy often do not register their activity for objective reasons.

\subsection{OLI: as a tool for measuring the online gig economy}

Researchers have been undertaking attempts to measure the online gig economy since approx. 2010. Major studies were conducted (cf. Ostoj, 2020, pp. 32-35) by Agrawal \& Lacetera (2013, pp. 219-250), Difallah et al. (2015, pp. 238-247), Horton et al. (2017, pp. 4-13), Ipeirotis (2010, pp. 16-21). What they had in common was that they were limited to one platform and sought to identify the characteristics of the gig worker, type of work, income, etc. Other approaches attempted to obtain information through interviews with experts in the field of online outsourcing (e.g., Kuek et al., 2015, pp. 28-40; Lehdonvirta \& Ernkvist, 2011, pp. 23-28).

The major breakthrough came in the form of Online Labour Index, a tool developed by the OII to measure the scale of the online gig economy, which through access to the significant amount of data - also allows some insight into the activity of gig workers and their structure. The authors of the tool define online labour platforms as enterprises through which buyers and sellers of services complete a transaction in an entirely digital manner, i.e., an order is placed and a task (e.g., a project) is completed online through the platform. This is also how payment is made and the final form of the order is received (Kässi \& Lehdonvirta, 2018, pp. 241-248). Based on observation and measurements 
of how most types of work (ranging from piecework to projects conducted by freelancers) were performed, the authors of the index selected a representative sample of five platforms: Upwork.com, Freelancer.com, Mturk.com, Peopleperhour.com, and Guru.com. These are the largest English-language platforms representing more than $70 \%$ of such transactions concluded worldwide. They also identified six groups of work (Kässi \& Lehdonvirta, 2018, pp. 241-248): (1) software development and technology; (2) creative and multimedia; (3) clerical and data entry; (4) writing and translation; (5) sales and marketing support; (6) professional services. The OLI-based measurement has been conducted since 3 May 2016 and it involves tracking the number of projects and tasks ordered via platforms (i.e. demand for online work), taking into account their structure by type of occupation and employer country. According to OII data, the dominant employer countries are: the USA, India, the UK, Canada, and Australia. These are the only countries singled out in the measurement. Other countries are grouped under larger categories, for example "other Europe".

\section{Methods}

The aim of the article required the examination of the supply side of the online gig economy. Since July 2017, the OII has also provided the OLI worker supplement, created using data obtained from the four largest online labour platforms (also referred to as online freelancing or online outsourcing platforms): Fiverr, Freelancer, Guru, and PeoplePerHour (Lehdonvirta, 2017). Each platform is sampled once a day and data such each worker's home country, occupation category, and latest project, are collected. These samples are then used to obtain complete information on the number of workers active at any given time across all platforms, by using weights calculated according to the number of workers on each platform. In 2019, the four platforms had approx. 3.5 million registered workers. From this population, about 100,000 worked at least once in a given week. The authors of the index estimated that globally this figure is at least twice as high (Kässi \& Lehdonvirta, 2018, pp. 241-248). Any worker who completed a task in at least the previous 28 days was described as "currently active". The number of hours each worker is active is not recorded, but it is possible to identify workers performing tasks of varying degrees of involvement; according to the authors of the index, software development projects can take ten times as long as data entry projects. Data on active workers are recorded in absolute terms. Finally, however, the number of workers in each country and by type of occupation is expressed as a share of their total number due to the fact that the absolute figures refer only to the sample.

The study was conducted in two stages. First, the countries whose workers have the largest share of the global online gig economy were selected according to the method described above. The examination of the supply structure is only possible based on partial daily readings, so the fluctuations that occur should be treated as natural. The observations conducted by the Author from September 
2019 revealed little change in the structure. Finally, data from four readings were taken: 19 September 2017, 2 March 2020, 3 August 2020, 3 March 2021.

The next step involved the evaluation of the determinants of labour supply in these countries, which was performed using the traditional approach applied in economic theory, with elements of the Author's original modification accounting for the nature of the online gig economy. The following groups of determinants were considered: demographic, economic, institutional and legal, and socio-cultural (Borjas, 2020, pp. 54-79; Kryńska \& Kwiatkowski, 2013, pp. 87-91). The variables representing each group of the determinants of labour supply were selected.

\section{Results}

Table 1 shows the results of four readings of the rankings of the top ten countries by worker's home country. If workers in a given country accounted for at least $3 \%$ of the total, this information is provided additionally.

The data revealed the relative stability of the top six countries by gig worker's home country. A third of the total number of gig workers come from India, which puts it in the first place. Bangladesh and Pakistan, which both have a similar share of gig workers, rank after India and are followed by the US, the UK and the Philippines, with the US share apparently the least stable. These six countries are the countries from which the majority of gig workers come.

Then, the selection and characterization of the variables describing the gig workers' home countries which, based on reference literature (Borjas, 2020, pp. 54-79; Kryńska \& Kwiatkowski, 2013, pp. 87-91), can be adopted as determinants of the supply structure of the online gig economy. Demographic factors concerned the population and digital competence in a given country. This characteristic was recognized as more important for the online gig economy than age, gender or education, which are taken into account in traditional labour market analysis. The study conducted in seven European countries (Huws et al., 2017, p. 30) established that all age groups were involved in the gig economy, with a slight dominance of 25-34 year olds, and their involvement was not related to education. In principle, gig workers were male more often than female, but in the United Kingdom and Italy the opposite was true, so gender does not seem to be of decisive importance in the case of the segment under examination. However, given the nature of gig work, it is the percentage of internet users that is crucial, as it reflects a minimum level of digital competence. Economic factors of labour supply usually focus on the prices of final goods and the level of remuneration (in this case, the price for a service). In the online gig economy, final goods are usually produced in a country different from the gig worker's home country, so the key indicator will be the ratio of the price for the service in the global market to the remuneration for an equivalent service in the domestic market. Relevant studies revealed that the valuation of work provided by online gig workers can be considered relatively low in relation to average or even 
minimum wages per hour of work in highly developed countries, but in poorer countries the price per task can be several times the minimum wage, therefore the amount of work performed by workers from these countries can be relatively high (De Groen \& Maselli, 2016, pp. 13-14). Additionally, payment per unit of work is subject to continuous downward pressure in the global market. Another economic determinant is access to welfare benefits (unemployment benefits, social aid, pensions), which could be an alternative to work income.

Institutional and legal factors comprise the size of the informal sector, where online gig workers tend to be based, and the degree of restrictiveness of labour market regulations, which - if high - blocks access to corporate jobs and forces workers to seek employment outside the formal sector. The retirement age and working time regulations, usually taken into account in labour market analyses, are irrelevant to the context of the online gig economy, as they do not apply to platform mediated work. Access to the internet, as a source of information both on jobs in the economy and on opportunities to work via platforms, can also be included in this group of determinants, but as it is expressed by the actual percentage of Internet users, it is included in the demographic variables.

Socio-cultural factors determining the supply of labour in the online gig economy, the status of the English language in each country was taken into account, as the world's work sharing platforms are run in English, whereas the presence of English language skills, if not native related, may have historical roots. Other work-related issues seem less relevant given the possibility of working from home and in flexible hours.

To sum up, these groups of determinants include seven variables which were identified as potentially relevant to the analysis of the share of gig workers in the global online gig economy by their home country. These are: the demographic variables - (1) population, (2) the percentage of internet users; the economic variables - (1) minimum hourly wage in the country and average hourly wage in the gig economy according to PPP USD (an average of USD 4.9 was assumed, cf. ILO, 202la, p. 155); (2) access to social benefits (unemployment benefits); the institutional and legal variables - (1) the size of the informal sector, (2) the degree of the restrictiveness of labour market regulations, measured with the Labour Freedom index, which is part of the Index of Economic Freedom (developed by the Heritage Foundation); and the socio-cultural variables - universal knowledge of English.

Table 2 shows these seven variables representing the main groups of determinants of the supply of work services, modified for the online gig economy, with regard to the six gig workers' home countries, in order to identify the characteristics of their socio-economic accounting for the high supply of work in the global online gig economy.

All the analyzed countries have relatively high populations, although the country with the world's largest population is absent. The country with the smallest population of the six analyzed countries is ranked 22nd in the world, 
while the four leading countries are in the top ten. The proportion of Internet users also varies, but combined with a large population size, even $30-40 \%$ of internet users can capture a significant share for a country's gig workers.

The comparison of a country's minimum hourly wage with the average hourly wage in the online gig economy (by PPP USD) reveals how attractive online jobs in the gig economy are to gig workers from developing countries. It may be profitable for them to accept assignments at relatively low rates in the global market, even though more than $60 \%$ of gig contractors from developing countries earn below-average rates (ILO, 202la, p. 155). In the case of the USA and the UK, it can be assumed that gig workers will perform tasks for rates significantly lower than the equivalent minimum wage in their country, which is caused by the lack of access to a better source of main or supplementary income (De Groen \& Maselli, 2016, pp. 13-14). Moreover, India, Bangladesh and Pakistan have huge informal sectors, including jobs outside agriculture, so performing online work in this sector can be considered a normal situation.

In the Asian countries, four of the six countries do not have the unemployment benefit as an exemplary form of the welfare benefit, so it is not an alternative to self-employment in the case of a job loss.

The Labour Freedom index was used to assess how restrictive labour market regulations are in the analyzed countries. It embraces seven components: the ratio of the minimum wage to the value added per worker, hindrance to hiring additional workers, rigidity of working time, difficulty of dismissing workers, a legally mandated notice period, mandatory severance pay, and the labour market participation rate. According to the interpretation provided by the authors of the index, India and Pakistan have repressed labour markets (the index stayed in the range 0-49.9), the Philippines - mostly unfree, Bangladesh moderately free, the UK - mostly free, and only the USA has a free labour market. Despite the existing differences demonstrated in the degree of restrictiveness of labour market regulations, we can distinguish two countries with a

significant level of labour market freedom and the remaining countries where labour market freedom is more or less limited. It is worthwhile to point out that the US labour market can be considered the least regulated in the world (together with Singapore; cf. Ostoj, 2017, pp. 1827-1834).

The societies of all the analyzed countries possess universal knowledge of English. In India, Pakistan and the Philippines, English is the official language. The territory of Bangladesh belonged to India under the British rule until 1947, so the knowledge of English is common and the language is an obligatory subject in schools. The USA and the United Kingdom have no national official language, but in practice it is English. 


\section{Discussion}

The nature of the online gig economy, developing on a global scale, makes it necessary to use modified and adjusted determinants of the supply of labour services. Based on the data presented in Table 2, the conclusion may be drawn that the domination of workers from specific countries in the online gig economy is the result of the co-occurrence of several characteristics of their socio-economic systems: universal knowledge of English in a large population, but with a certain threshold percentage of Internet users, the relative financial attractiveness of jobs in the global online gig economy, and the significant size of the informal sector or the presence of labour freedom, as shown in Scheme 1.

The above configuration of factors determining the participation of online gig workers from these countries in the global online gig economy seems to explain the absence of China or Brazil (the sixth most populated country in the world). The absolute prerequisite for a high share of gig workers from a given country in the online gig economy seems to be universal knowledge of English. The remaining factors are more complex. Population needs to include a certain threshold percentage of internet users; it stays at around 30-40\% for the most populated countries. Participation in the global online gig economy should be economically attractive to gig workers (before they become aware of the instability of work and income as well as other risks associated with working via platforms) or be the only way to earn an income in the absence or low levels of welfare benefits. Therefore, interested in online gig work will be people who do not have a chance to find a legal job (they look for it in the informal sector, which is growing), due to the high degree of restrictiveness of labour market regulations and/or when the minimum wage (if any) is much lower than the wage paid in the global online gig economy (as in developing countries) or in highly developed countries - it is an important source of income (main or supplementary).

The domination of online gig workers from India, Bangladesh and Pakistan, as well as the Philippines, is referred to as the geography of precarity (Strauss, 2018, pp. 622-630). Its growing significance may turn out to be particularly severe in the future, as it stems from direct participation in the global market and it is difficult to regulate it through national legislation. The presence of the USA and the UK in the group of the countries with the largest number of gig workers can be explained both by the demographic and language factor and by a high degree of Labour Freedom (and Economic Freedom in general). Additionally, digital platforms were first developed in the USA and quickly adopted in the UK. These countries are also characterized by high income inequalities (as compared with other highly developed countries); a Gini index of 41.4 for the US and 34.8 for the UK (in 2019; UNDP, 2020, pp. 351-354) is associated with the existence of relatively low-income groups willing to earn additional income and the online gig economy is ideally positioned to provide it. 


\section{Conclusion}

The majority of the identified determinants of the supply of labour in the global online gig economy in the analyzed countries are institutional in nature (broadly defined formal and informal institutions); while universal knowledge of English is a cultural variable, the remaining ones stem from systemic solutions. In the Asian countries from which most global online gig workers come, the price of labour is very low, welfare security is absent, and the informal sector engages a larger share of labour resources, which is reinforced by relatively restrictive labour market regulations. On the other hand, Internet access rates and the proportion of Internet users are sufficiently high. The combination (co-occurrence) of these factors can be regarded as a set of conditions that explain the large numbers of online gig workers coming from the analyzed Asian countries. The conditions discussed in the previous section also explain the strong position of US- and UK-based gig workers in the global online gig economy. It can be predicted that, gradually, countries with institutional infrastructure similar to the two groups of countries analyzed above, which already feature as gig workers' home countries, such as Kenya, Nigeria, and Australia, will play an increasingly important role. They will contribute to establishing the balance of forces on the labour supply side of the global online gig economy.

\section{References}

Agrawal, H., \& Lacetera, L. (2013). Digitization and the contract labour market: a research agenda. NBER Working Paper, 1952, 1-36. https://doi. org/10.3386/w19525.

Bogenhold, D., Klinglmair, R., \& Kandutsch, F. (2017). Solo self-employment, human capital and hybrid labour in the gig economy. Foresight and STI Governance, 11(4), 23-32. https://doi.org/10.17323/2500-2597.2017.4.23.32.

Borjas, G.J. (2020). Labour economics. McGraw Hill.

CIA. (2021). The world factbook. Retrieved 07.02.2021 from https://www.cia. gov/the-world-factbook/countries.

De Groen, W., \& Maselli, I. (2016). The impact of the collaborative Economy on the labour market. CEPS Special Report, 138, 1-35.

De Stefano, V. (2016). The rise of the "just-in-time workforce": on demand work and the labour protection in the "gig economy". Retrieved 07.02.2021 from https://www.ilo.org/wcmsp5/groups/public/---ed_protect/ - --protrav/ - -travail/documents/publication/wcms_443267.pdf.

Difallah, D.E., Catasta, M., Demartini, G., Ipeirotis, P.G., \& Cudre-Mauroux, P., (2015). The dynamics of micro-task crowdsourcing: the case of Amazon MTurk. In Proceedings of the 24th International Conference on World Wide Web Committee (pp. 238-247). https://doi.org/10.1145/2736277.2741685. 
Farrell, D., \& Greig, F (2016). Paychecks, paydays, and the online platform economy: big data on income volatility. Retrieved 20.03.2020 from https://www. jpmorganchase.com/content/dam/jpmc/jpmorgan-chase-and-co/institute/pdf/jpmc-institute-volatility-2-report.pdf.

Florisson, R., \& Mandl, I. (2018). Platform work: types and implications for work and employment: literature review. Retrieved 20.03.2020 from https://www. eurofound.europa.eu/sites/default/files/wpefl8004.pdf.

Graham, M., \& Anwar, M.A. (2019). The global gig economy: towards the planetary labour market. First Monday, 24(4). https://doi.org/10.5210/ fm.v24i4.9913.

Horton, J., Kerr, W.R., \& Stanton, C. (2017). Digital labour markets and global talent flows. NBER Working Paper, 23398, 1-42. https://doi.org/10.3386/ w23398.

Howcroft, D., \& Bergvall-Kareborn, B. (2019). A typology of crowdwork platforms. Work, Employment and Society, 33(1), 21-38. https://doi. org/10.1177/0950017018760136.

Hunt, A., \& Samman, E. (2019). Gender and the gig economy: critical steps for evidence-based policy. Evidence Ideas Change: Working Paper, 546, 1-48.

Huws, U., Spencer, N.H., Syrdal, D.S., \& Holts, K. (2017). Work in the European gig economy: research results from the UK, Sweden, Germany, Austria, the Netherlands, Switzerland and Italy. Retrieved 20.03.2020 from https://uhra.herts. ac.uk/bitstream/handle/2299/19922/Huws_U._Spencer_N.H._Syrdal_D.S._Holt_K._2017_.pdf.

ILO. (2018). Women and men in the informal economy: a statistical picture. Retrieved 20.03.2020 from https://www.ilo.org/wcmsp5/groups/public/ - - dgreports/- - -dcomm/documents/publication/wcms_626831.pdf.

ILO. (2021a). World employment and social outlook: the role of digital labour platforms in transforming the world of work. Retrieved 20.03.2020 from https:// www.ilo.org/wcmsp5/groups/public/ - - dgreports/ - - dcomm/ - - -publ/ documents/publication/wcms_771749.pdf.

ILO. (2021b). Retrieved 27.02.2021 from https://ilostat.ilo.org/topics/wages.

Internet World Stats. (2021). Retrieved 02.02.2021 from https://www.internetworldstats.com/stats3.htm.

Ipeirotis, P.G. (2010). Analyzing the Amazon mechanical turk marketplace. XRDS: Crossroads: The ACM Magazine for Students, 17(2), 16-21. https://doi. org/10.1145/1869086.1869094.

Kässi, O., \& Lehdonvirta, V. (2018). Online labour index: measuring the online gig economy for policy and research. Technological Forecasting and Social Change, 137, 241-248. https://doi.org/10.1016/j.techfore.2018.07.056.

Kessler, S. (2018). Gigged: the end of the job and the future of work. St. Martin's Press.

Kryńska, E., \& Kwiatkowski, E. (2013). Podstawy wiedzy o rynku pracy. Uniwersytet Łódzki. 
Kuek, S.C., Paradi-Guilford, C., Fayomi T., Imaizumi, S., \& Ipeirotis, P. (2015). The global opportunity in online outsourcing. Retrieved 02.02.2021 from https://openknowledge.worldbank.org/handle/10986/22284.

Lehdonvirta, V. (2017). Where are online workers located: the international division of digital gig work. Retrieved 31.01.2021 from https://ilabour.oii.ox.ac. uk/where-are-online-workers-located-the-international-division-of-digital-gig-work.

Lehdonvirta, V., \& Ernkvist, M. (2011). Knowledge map of the virtual economy: converting virtual economy into development potential. Retrieved 02.02.2021 from https://openknowledge.worldbank.org/handle/10986/2736l.

Miller, T., Kim, A.B., \& Roberts, J.M. (2020). Highlights of the index of economic freedom. Retrieved 02.02.2021 from https://www.heritage.org/index/pdf/2020/book/2020_IndexofEconomicFreedom_Highlights.pdf.

Minter, K. (2017). Negotiating labour standards in the gig economy: Airtasker and Unions New South Wales. The Economic and Labour Relations Review, 28(3), 438-454. https://doi.org/10.1177/1035304617724305.

Ostoj, I. (2017). Inevitable level of labour market in the globalization era. In T. Kliestik (Ed.), Globalization and its socio-economic consequences (pp. 18271834). University of Zilina.

Ostoj, I. (2020). Praca w czasach cyfrowych platform technologicznych: w sieci gig economy. Uniwersytet Ekonomiczny w Katowicach.

Parker, G., van Alstyne, M., \& Choudary, S. (2016). Platform revolution: how networked markets are transforming the economy and how to make them work for you. W.W. Norton.

Prassl, J. (2018). Humans as a service. Oxford University Press. https://doi. org/10.1093/oso/9780198797012.001.0001.

Radonjic-Simic, M., \& Pfisterer D. (2019). Beyond platform economy: a comprehensive model for decentralized and self-organizing markets on Internet scale. Computers, 8(4), 1-44. https://doi.org/10.3390/computers8040090.

Stanford, J. (2017). The resurgence of gig work: Historical and theoretical perspective. The Economic and Labour Relations Review, 28(3), 382-401. https:// doi.org/10.1177/1035304617724303.

Stewart, A., \& Stanford, J. (2017). Regulating work in the gig economy: what are the options. The Economic and Labour Relations Review, 28(3), 420-437. https://doi.org/10.1177/1035304617722461.

Strauss, K. (2018). Labour geography I: towards a geography of precarity. Progress in Human Geography, 42(4), 622-630. https://doi. org/10.1177/0309132517717786.

UNDP. (2020). Human development report 2020: the next frontier and the Anthropocene. Retrieved 15.03.2021 from http://hdr.undp.org/sites/default/files/ hdr2020.pdf. 


\section{Acknowledgements}

Author contributions: author has given an approval to the final version of the article.

Funding: this research was fully funded by the University of Economics in Katowice, Faculty of Economics statutory resources.

Note: the results of this study were presented at 4th Scientific Conference: Institutions in Theory and Practice (March 25-26, 2021, Wrocław, Poland). 


\section{Appendix}

Table 1.

Top countries by the share of their workers in the global online gig economy (\%)

\begin{tabular}{cccc}
\hline 19 September 2017 & 2 March 2020 & 3 August 2020 & 3 March 2021 \\
\hline India (24) & India (35.5) & India (34) & India (33) \\
Bangladesh (15.5) & Bangladesh (12) & Bangladesh (12) & Pakistan (13.5) \\
USA (12) & Pakistan (11) & Pakistan (11) & Bangladesh (12.5) \\
Pakistan (8) & USA (6) & USA (10.9) & United Kingdom (4.5) \\
Philippines (6.5) & United Kingdom (4) & United Kingdom (4) & USA (4) \\
United Kingdom (6) & Philippines (3) & Philippines (3) & Philippines (3) \\
Ukraine & Ukraine & Ukraine (3) & Russia \\
Canada & Russia & Russia & Ukraine \\
Romania & Indonesia & Indonesia & Egypt \\
Egypt & Sri Lanka & Egypt & Indonesia \\
Germany & Egypt & Sri Lanka & Serbia \\
Russia & Australia & Serbia & Kenya \\
Kenya & China & Australia & Sri Lanka \\
Nigeria & Canada & Kenya & Australia \\
Italy & Kenya & Canada & Vietnam \\
\hline
\end{tabular}

Source: Own preparation based on Lehdonvirta (2017).

Table 2.

Selected variables representing the determinants of the supply or work services in the online gig economy

\begin{tabular}{|c|c|c|c|c|c|c|}
\hline Variable & India & Bangladesh & Pakistan & USA & UK & Philippines \\
\hline \multirow{3}{*}{$\begin{array}{l}\text { population (billion; \% of world popula- } \\
\text { tion; rank; 2021) }\end{array}$} & 1.34 & 0.164 & 0.238 & 0.334 & 0.066 & 0.110 \\
\hline & 17 & 2.1 & 3.1 & 4.3 & 0.8 & 1.4 \\
\hline & 2 & 8 & 5 & 3 & 22 & 13 \\
\hline percentage of Internet users (\%; 2020) & 40.6 & 58.4 & 32.4 & 95.6 & 94.9 & 72.1 \\
\hline \multirow{2}{*}{$\begin{array}{l}\text { minimum hourly wage and average hourly } \\
\text { wage in the gig economy (converted at } \\
\text { PPP USD; 2018) }\end{array}$} & 1.07 & 1.47 & 3.06 & 7.86 & 10.83 & 3.21 \\
\hline & 16.42 & 12.00 & 15.79 & 4.9 & 5.29 & 11.07 \\
\hline $\begin{array}{l}\text { access to social benefits (unemployment } \\
\text { benefits after l year of employment / } \\
\text { minimum length of contribution period; } \\
\text { 2019) }\end{array}$ & absence & absence & absence & $\begin{array}{c}6-12 \\
\text { months }\end{array}$ & yes $/ 0$ & absence \\
\hline $\begin{array}{l}\text { percentage of those working in the in- } \\
\text { formal sector, outside agriculture, as } \\
\text { a percentage of all those working outside } \\
\text { agriculture (2018) }\end{array}$ & 78.1 & 82.0 & 70.8 & 18.3 & 13.4 & - \\
\hline $\begin{array}{l}\text { labour market regulations (Labour Free- } \\
\text { dom, 2020) }\end{array}$ & 41.2 & 6.4 & 41.3 & 87.9 & 73.1 & 57.4 \\
\hline english language status (knowledge) & official & universal & official & universal & universal & official \\
\hline
\end{tabular}

Source: Own preparation based on CIA (2021); ILO (2018; 2021b); Internet World Stats (2021); Miller et al. (2020). 
Scheme 1 .

Determinants of the dominance of the supply of labour services from particular countries in the online gig economy

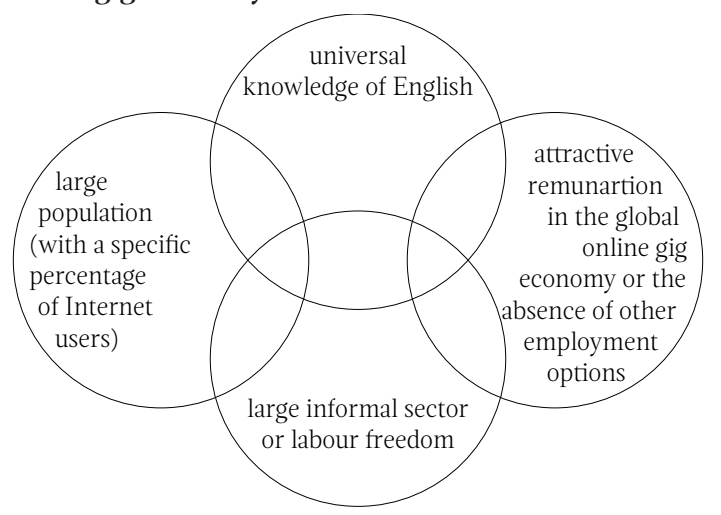

Source: Own preparation. 
